\title{
STEM Approach: The Development of Optical Instruments Module to Foster Scientific Literacy Skill
}

\author{
*Noly Shofiyah, Metatia Intan Mauliana, Istiqomah, Ria Wulandari \\ Natural Science Education Department, Fakultas Psikologi dan Ilmu Pendidikan, Universitas \\ Muhammadiyah Sidoarjo. Jl. Majapahit 666B, Sidoarjo 61215, Indonesia \\ *Corresponding Author e-mail: nolyshofiyah@umsida.ac.id
}

Received: February 2021; Revised: July 2021; Published: July 2021

\begin{abstract}
STEM is an approach that seemly considered helpful in online learning because it can facilitate students to learn about 21st-century skills. This study aimed to develop module-based STEM in improving scientific literacy skills in distance learning through e-learning. Because this research developed module-based STEM, this study was named developmental research. The research procedure follows the stages of the R \& D method developed by Barg and Gall, including preliminary, product planning, development, validation (validation by experts), revision, and field testing. Modules that have been declared valid by experts are field-tested using one group pretest-posttest design in an experimental class. The results show that the feasibility of module-based STEM in the distance learning model to increase students' skills within scientific literacy was valid with an average score of 4.28 by two experts. In addition, the application of integrated STEM teaching materials through e-learning has a moderate effect on students' scientific literacy skills since the N-gain score was 0.6.
\end{abstract}

Keywords: STEM; Module; Scientific Literacy

How to Cite: Shofiyah, N., Mauliana, M. I., Istiqomah, I., \& Wulandari, R. (2021). STEM Approach: The Development of Optical Instruments Module to Foster Scientific Literacy Skill. Jurnal Penelitian Dan Pengkajian Ilmu Pendidikan: E-Saintika, 5(2), 92-103. https:// doi.org/10.36312/esaintika.v5i2.388

\section{INTRODUCTION}

The 21st century is the era where technological development is very rapid and caused a significant impact, especially on the changes in the education sector. Therefore, Rahayu (2017) stated that 21st-century skills are necessary to ensure the students be able to overcome the 21st-century's challenges, it consists of the literacy of digital-age, creative thinking, communication effectiveness and high productivity. The skills of digital-age literacy are in line with NCREL, and it comprises basic, scientific, economic, technological, visual, information, and multicultural literacy (van Laar et al., 2017).

Scientific literacy is one of the crucial competencies to increase knowledge and problem-solving skills (Nurtanto et al., 2018). Scientific literacy is directly connected with the scientific understanding concepts and processes required for personal decision-making, civic and cultural affairs participation, and economic productivity (Rusilowati et al., 2016). Scientific literacy needs to be delivered to the current generation because it can direct them to have strong scientific thoughts and attitudes and effective communication to the general public (Dewi et al., 2019). In PISA 
(Program for International Students Assessment), scientific literacy means three competencies: students can recognize the science issues (problems), phenomena scientifically explanation, and apply scientific evidence.

The government has carried out various policies in order to improve students' skills of scientific literacy in Indonesia, including the change of the curriculum from the KTSP to the 2013 curriculum until the High Order Thinking Skills (HOTS) questions type application in the National Examination. However, the results are not very encouraging because, according to the outcomes of the PISA finding in 2018, the low scores of Indonesian students' skills in scientific literacy are still founded. Mostly, Indonesian student's score in scientific literacy is still below the determined score of 489 , the Indonesian student's score is about 396. In science assessment, Indonesia is in the ninth rank from the bottom compared to the other OECD countries (OECD, 2019).

This prompted the government to make a new policy in the form of eliminating the National Examination and changing it to the Minimum Competency Assessment or called AKM (Asesmen Kompetensi Minimum) starting in 2021. As stated by the Minister of Education and Culture Nadiem Makarim, quoted from kompas.com in 2019, the $A K M$ is an assessment that measures the minimum skills needed by students to be able to learn and is a form of simplification of the National Examination, which is so complex. The material consists of only three, namely literacy, numeracy, and strengthening character education (Muliani et al., 2021). The literacy and numeracy material in the AKM questions refers to PISA.

Given that the AKM questions measure students' scientific literacy, the teacher should practice scientific literacy skills in science learning so that students are ready to face AKM. However, currently, the world is being hit by the Covid-19 (Coronavirus Disease 2019) pandemic, because of it, many sectors are impacted in Indonesia, with no exception for the educational sector. During this pandemic, the Minister of Education and Culture issued circular number 36962 / MPK.A / HK / 2020, which obliged all learning to be carried out online. However, some students considered online learning boring (Oliveira et al., 2018) and only focused on understanding the students' concepts (Picciano, 2017). Teachers rarely practice scientific literacy skills for students.

The optical instruments topic is one of the materials accommodated within physics learning in high school on basic competencies 3.11 Examining the optical instruments working by applying the light reflection and refraction properties through mirrors and lenses and 4.11 Creating works which use the reflection principle or a refraction towards mirrors and lenses. The concepts of optical instruments are closely related to everyday life. Still, various educational research shows the difficulty and obscurity of the light topic and optical instrument (Galili \& Hazan, 2000). The concept is complex and difficult, leading to the student's misconceptions (Ling, 2017). In addition, based on the basic competencies in the 2013 curriculum, students are expected to understand concepts and work on making a simple optical device. However, most teachers only focus on the cognitive realm (Anindya \& Wusqo, 2020), so basic competence in skills is rarely achieved.

Referring to the solution of problems about online learning that do not train scientific literacy skills and lack of student skills in making an optical instrument product, something is needed that can make students active in learning and practice scientific literacy skills, namely by Module-based STEM. The STEM integrated teaching materials application can increase the competencies of scientific literacy 
(Widayoko et al., 2018). STEM learning is seen as an approach capable of providing significant changes in the 21st century (Widya et al., 2019). Scientific literacy skills, which are part of the 21st-century skills, by using STEM-based science learning, it could be achieved (Afriana et al., 2016; Ismail et al., 2016; Wahyu et al., 2020; Lestari et al., 2021). HACIOĞLU et al., (2016) stated that to increase the interest of the Indonesian young generation in technology, engineering, science, and mathematics, learning in schools must be carried out according to educational patterns that include STEM aspects, namely technology, engineering, science, and mathematics. In the development of the 21st century, appropriate learning is learning with the STEM approach, where STEM integrates technology, engineering, science, and mathematics in learning that is carried out (Widarti et al., 2020). Meanwhile, Kelley and Knowles (2016) define STEM as an approach that can train STEM science two or more fields, namely technology, engineering, science, and mathematics. Through this approach, the learning process discuss not only science but also its practice in real life.

In order to help students learn optical instruments more easily with the STEM approach, a module is needed. The module itself is a teaching material that trains students' independence in learning (Risdianto et al., 2020) Arifa. Several previous researchers stated that the module integrated with the STEM approach supported the achievement of scientific literacy skills (Prasetyo et al., 2021). One of the themes of the module integrated STEM that has been studied is Microscope Smartphone by measuring students' understanding of concepts (Dewati et al., 2019). In this study, the module was developed on the theme of the Smartphone Projector from Cardboard to train students' scientific literacy. Therefore, the purpose of the study is to describe the Module-based STEM and explain the effect of Module-based STEM that is implemented in e-learning on students' scientific literacy skills.

\section{METHOD}

\section{Research Design and Procedures}

This research is a research development because Borg and Gall developed the Module-based development with the R and D (Research and Development) method (Buchori \& Setyawati, 2015). here was two main objectives of development research, namely, product development and the product effectiveness tested in order to achieve the goals. This study's research and development procedures include the studies of preliminary, design, development, validation, revision of the product, field testing, and final products. Preliminary studies are used by researchers to analyze needs, review literature, and identify factors that cause problems so that there is a need to develop Modul-based STEM. Furthermore, the researchers began to determine the design of Module-based STEM including designs, components, materials, drawings that are discussed with other research members. Product development is the stage of making Module integrated STEM and also scientific literacy tests. Two experts then validated the modules and scientific literacy tests that were compiled.

The final product produced was then subjected to field trials through e-learning involving 30 students of class XI-D IPA for the 2020/2021 academic year to determine the effect of Module-based STEM on students' scientific literacy. The research design when trying out the module in the classroom is described as follows.

$\begin{array}{llll}\text { Experiment class } & \mathrm{O} 1 & \mathrm{X} & \mathrm{O} 2\end{array}$


In this study, the students' scientific literacy skills were measured at the field testing stage 2 times, namely before and after the implementation of the Module-based STEM.

\section{Instruments}

This study used a scientific literacy test as the instrument that was prepared based on three scientific literacy indicators, consisting of scientific reasoning and inquiry, problem solving, and the basic competencies of optical instrument material. The grid of scientific literacy skills instruments shows in Table 1. Before the scientific literacy test instrument was used in this research, the validation of the instrument was done by two experts.

Table 1. Science Literacy Test Grid

\begin{tabular}{|c|c|c|}
\hline $\begin{array}{l}\text { Indicator of Scientific } \\
\text { Literacy }\end{array}$ & Learning Objectives & $\begin{array}{c}\text { Item } \\
\text { Number }\end{array}$ \\
\hline Scientific Inquiry & $\begin{array}{l}\text { 1. Determining the experiment variables } \\
\text { 2. Making Conclusion }\end{array}$ & $3,4,5$ \\
\hline Scientific Reasoning & $\begin{array}{l}\text { 3. Giving reason scientifically of phenomena about } \\
\text { optical instruments }\end{array}$ & $6,8,9$ \\
\hline Problem Solving & $\begin{array}{l}\text { 4. Giving the alternative solution of daily problems } \\
\text { about optical instruments }\end{array}$ & $1,2,7$ \\
\hline
\end{tabular}

\section{Data Analysis}

The criterion that is written in Table 2 is the criteria used to analyze the validation results of the module and scientific literacy test (instruments). Besides providing the grades, the experts also offer comments for module improvements.

Table 2. Criteria of Validation Results

\begin{tabular}{cc}
\hline Score Interval & Category \\
\hline $\mathrm{Va}=5$ & Very Good/Valid \\
$4 \leq \mathrm{Va}<5$ & Good/Valid \\
$3 \leq \mathrm{Va}<4$ & Adequate/Valid \\
$2 \leq \mathrm{Va}<3$ & Poor/Not Valid \\
$1 \leq \mathrm{Va}<2$ & Very Poor/Not Valid \\
\hline
\end{tabular}

In determining the Module-based STEM effect on scientific literacy skills, an Ngain score analysis was carried out.

$$
\langle g\rangle=\frac{S \text { post }-S \text { pre }}{S \max -S \text { pre }}
$$

The results of normalized gain calculations are categorized according to classification (Hake, 1999).

Table 2. N-Gain Criteria

\begin{tabular}{cc}
\hline Gain Score & Category \\
\hline$>0.7$ & High \\
$0,7>\mathrm{g}>0,3$ & Medium \\
$<0,3$ & Low \\
\hline
\end{tabular}




\section{RESULTS AND DISCUSSION}

The following descriptions are the gained results and discussions of this study consisting of the feasibility of the development of Module-based STEM and the clarification of the Module effectiveness to the scientific literacy skills.

\section{The feasibility of The Module}

One of the famous private high schools in Sidoarjo is where the research was conducted, on 2020/2021 school year in the even semester. The analysis stage is carried out by analyzing the basic competencies of physics subjects to be integrated with the STEM approach. The basic competencies selected are 3.11 optical instrument workings analyse using light reflection and refraction properties through lenses and mirror and 4.11 Applying the reflection and refraction principle towards lenses and mirrors to create works. In the analysis of the basic competency 3.11 and 4.11 , then it is broken down into six indicators which are then analyzed referring to the disciplines of technology, engineering, science, and mathematics in the learning to be designed, can be seen in Table 3.

Table 3. Analysis of Competency Achievement Indicators

\begin{tabular}{|c|c|c|}
\hline Comp & etency Achievement Indicators & Disciplines \\
\hline 3.11 .1 & $\begin{array}{l}\text { Describing the components of an optical } \\
\text { apparatus }\end{array}$ & Science \\
\hline 3.11 .2 & $\begin{array}{l}\text { Describing the function of each component of an } \\
\text { optical instrument }\end{array}$ & Science \\
\hline 3.11 .3 & Analyzing the operation of optical instrument & Science, Technology \\
\hline 3.11 .4 & $\begin{array}{l}\text { Determining the nature of the image produced by } \\
\text { the optical instrument }\end{array}$ & Science \\
\hline 3.11 .5 & $\begin{array}{l}\text { Determining the magnification of the image } \\
\text { produced by the optical device }\end{array}$ & Mathematics \\
\hline 4.11 .1 & $\begin{array}{l}\text { Making simple optical devices that can be used in } \\
\text { everyday life. }\end{array}$ & $\begin{array}{l}\text { Science, Technology, } \\
\text { Engineering, } \\
\text { Mathematics. }\end{array}$ \\
\hline
\end{tabular}

The developed module contains material for optical instruments, including eyes, cameras, loops, projectors, microscopes and telescopes. Each discussion of an optical instrument starts with the components of an optical instrument, the function of each optical instrument component, the working mechanism of the optical instrument, calculating the magnification of the image produced by an optical instrument. There is also a student worksheet about making a simple optical instrument in the developed module, namely a smartphone projector from cardboard. Each section on the student worksheet contains the STEM approach integration, they are the disciplines of technology, engineering, science, and mathematics. The STEM attribute in the module shows in Table 4 . The students' scientific literacy skills who gained STEM learning will automatically increase because they will be more literate in STEM aspects (Khaeroningtyas et al., 2016). 
Table 4. The Example of STEM Attribute in the Module

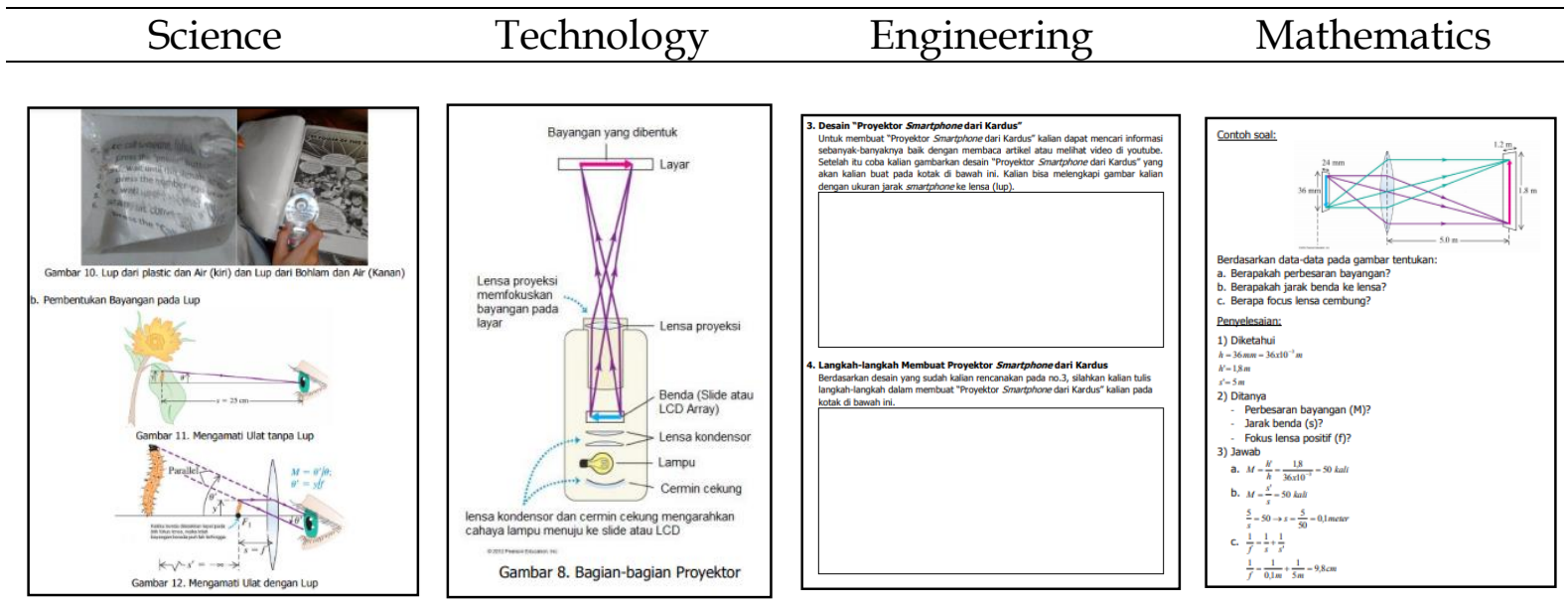

After the Module-based STEM with Optical Instrument has been developed, an expert validation test is conducted. The aspects assessed in the expert validation test step are the material's content, language, and appearance-The results of validation are displayed in Table 5.

Table 5. Validation Result of The Module-based STEM

\begin{tabular}{llcc}
\hline No & Aspects & Score & Category \\
\hline 1 & Material Content & 4.35 & Good/Valid \\
2 & Language & 4.00 & Good / Valid \\
3 & Appearance & 4.50 & Good / Valid \\
\hline Average & 4.28 & Good / Valid \\
\hline
\end{tabular}

There are three aspects based on Table 5 validation results, namely substantial content, language, and appearance which got scores respectively $4.35 ; 4.00 ; 4.50$. The average validation score is 4.28 . So it can be stated that the Module-based STEM that has been validated is categorized as valid or suitable to be implemented in online learning. The aspects assessed in the feasibility component of material content are material coverage, material accuracy, up-to-date, stimulating curiosity, and developing scientific literacy skills. These aspects lead to how the module presents concepts scientifically, has novelty, and trains scientific literacy skills. According to Puspitasari et al. (2019), teaching materials should have the following characteristics: (1) presenting factual, conceptual, and procedural learning materials; (2) integrated; (3) student-centered; and (3) oriented to scientific literacy. Students' scientific literacy is significantly improved at each domain through the quality science textbooks implementation in teaching and learning activities. (Sinaga et al., 2017)

The second component of feasibility was language in terms of accuracy in the use of language and according to the General Guidelines for Indonesian Spelling. Based on the score obtained on the language aspect, it is known that the Module-based STEM has used the correct Indonesian language rules. According to Panjaitan et al., (2021), the accuracy of language in the textbook is ensured that double interpretation will not be occurred, and the information can be learned and understood by the readers. Sinaga et al., (2017) also stated that textbooks with high readability would facilitate students processing and understanding the textbooks' information or the content easily. When students can easily understand the information in the module, it will accommodate students to learn about scientific literacy skills. 
The last component of feasibility was the appearance of the module. In this component, there are three indicators, namely cover design, systematic arrangement of modules, as well as clarity of display of images and tables. The first indicator is the presentation of the cover design. The cover design of this module is adjusted to the combination of colors, images, shapes, and sizes of letters that match to describe the contents of the module. Muswita et al., (2020) stated that the harmonious combination of colors, letters, and cover images can provide an overview of the content so that it can attract readers' interest. The second indicator is a systematic arrangement of module. This module was arranged sequentially from the cover, list contents, pictures, information about optical instruments, student worksheets integrated STEM and references. The sequence arrangement of the module components aims to build the readers' thinking power easier while reading the module. In line with Rizawayani et al., (2017) When read an object, the readers' thinking power in receiving the information or knowledge will be built by applying the systematic presentation. The last indicator is the clarity of the images and tables display. The display of pictures and tables has to be understandable so that learning is carried effectively (Paramita et al., 2018).

Modules that have been validated are still being corrected based on the expert's suggestions, which are displayed in Table 6.

Table 6. Suggestion and Refinement

\begin{tabular}{|c|c|}
\hline Suggestion & Refinement \\
\hline $\begin{array}{l}\text { 1. The image sizes of rods and cones } \\
\text { are too small. }\end{array}$ & $\begin{array}{l}\text { 1. Enlarge the image size of rods and } \\
\text { cones in the eye. }\end{array}$ \\
\hline $\begin{array}{l}\text { 2. The image forming the image on } \\
\text { the reflecting telescope is less clear. }\end{array}$ & $\begin{array}{l}\text { 2. Clarify the image formation of the } \\
\text { image on the reflecting telescope. }\end{array}$ \\
\hline $\begin{array}{l}\text { 3. The image of the image formation } \\
\text { on the loop is less clear. }\end{array}$ & $\begin{array}{l}\text { 3. Clarify the image formation of the } \\
\text { image on the loop. }\end{array}$ \\
\hline $\begin{array}{l}\text { 4. The projector image is not big } \\
\text { enough }\end{array}$ & $\begin{array}{l}\text { 4. Enlarges the projector image size } \\
\text { 5. Changing the word "under a }\end{array}$ \\
\hline $\begin{array}{l}\text { 5. The choice of the word "under a } \\
\text { microscope" is replaced by "using } \\
\text { a microscope". }\end{array}$ & microscope" to "using a microscope". \\
\hline
\end{tabular}

\section{Student's Scientific Literacy}

An n-gain score analysis is performed to determine the effect of Module-based STEM on Students' Scientific Literacy. Before the N-gain test, the data obtained were tested whether the data was distributed normally. In accordance to the KolmogorovSmirnov test, the significance value result was 0.218 greater than 0.05 . In other words, the data were normally distributed. Therefore, this research used N-Gain to measure the improvement of students' skill on scientific literacy. The pre-test and post-test scores of students on scientific literacy skills are revealed in Table 6.

Table 6. The average pre-test, post-test, and N-gain scores

\begin{tabular}{ccccc}
\hline $\mathrm{N}$ & Pre-Test & Post-Test & N-Gain & Category \\
\hline 30 & 44.81 & 76.30 & 0.5 & Medium \\
\hline
\end{tabular}


The results of the scientific literacy test illustrate the extent to which students master the optical instrument material. Regarding the pre-test and post-test results revealed in Table 6, it can be seen that the Module-based STEM has a moderate effect in helping students master scientific literacy skills.

This study measured some scientific literacy indicators, namely scientific reasoning, scientific investigation, and problem-solving. On Table 5, the students' pretest scores can be known that the three classes' score were low. In other words, before the learning implementation with the STEM approach, students' scientific literacy skills were in a low category. Students are less able to explain scientifically a phenomenon related to optical devices, solve problems about the implementation of optical devices in everyday life, and identify problems and variables that will be studied in an experiment.

In contrast to the pre-test results, the mean scores of post-test scientific literacy in both the experimental and the replication clasand replication classes 1 and 2 describe that the students' skills in scientific literacy are decent. Students are capable to define the exact solution of a given optical instrument problem, provide reasons in accordance with scientific concepts and determine research problems and variables in an experiment to find the magnification of optical instruments. This proves that the module-based STEM implemented in e-learning, can help students master the concepts and skills of scientific literacy in the material of optical instruments.

\section{ukuran jarak smartphone ke lensa (lup).}

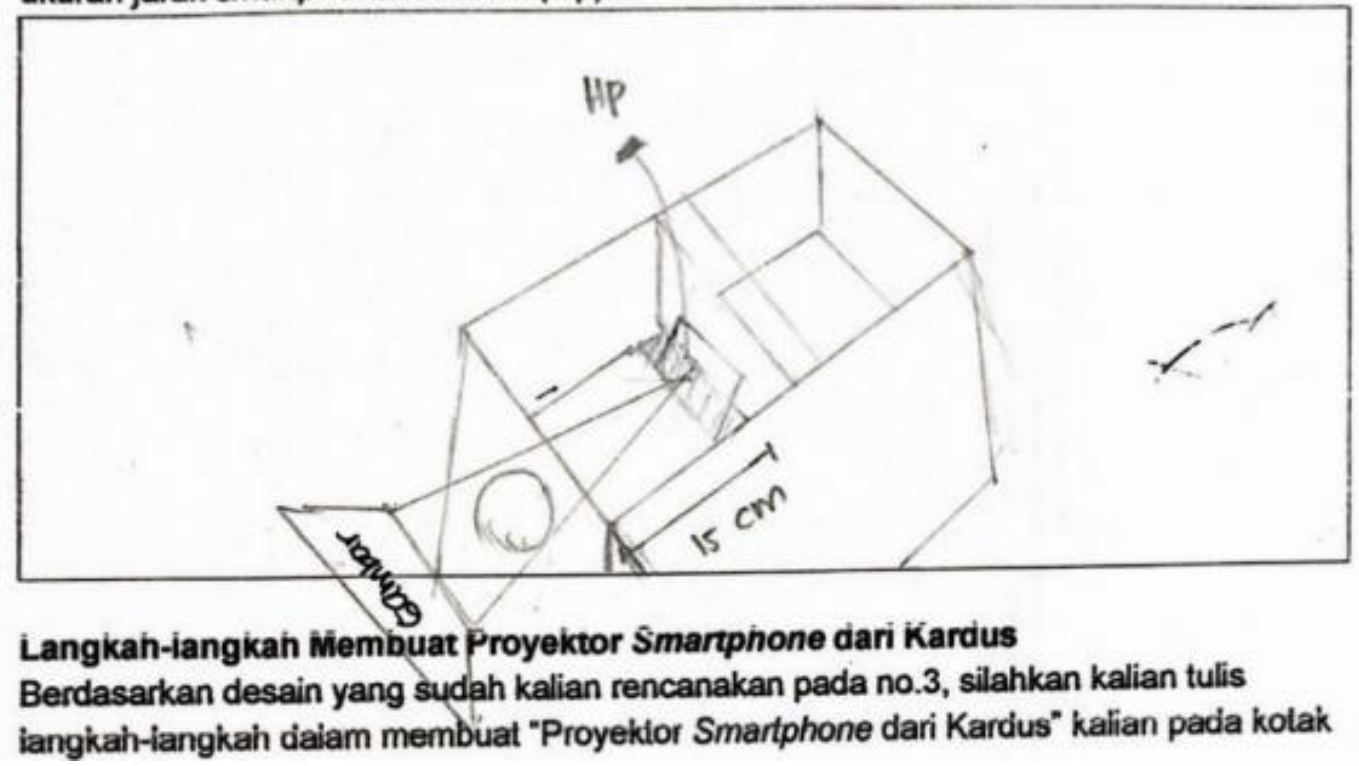

Figure 1. Designing the Projector from Cupboard

Module-based STEM, which is implemented in e-learning, plays a crucial part in training students' scientific literacy skills. Apart from the module providing scientific concepts about optical instruments, the module also facilitates students to practice being engineers. Students are asked to design a simple projector from cardboard based on a smartphone (Figure 1). Based on the designs that have been made, students are then asked to make the product and test it whether the projector product can function properly. In other words, the projector is said to be working if it is capable of producing a clear and enlarged image. Students are trained to have problem problemsolving abilities at this stage because when the projectors that are made are not able 
to produce a clear image, students will try to find alternative solutions so that the projectors that are made work well. After the projector is able to produce a clear and enlarged image, students are required to calculate the magnification produced by the projector and determine the focus size of the convex lens used. Listiana et al., (2019) explained that The STEM learning approach could facilitate students to develop their scientific literacy skills because the engineering techniques design procedure knowledge is given to the students. Afriana et al., (2016) also revealed that in the PjBL STEM learning, students were directed to design and make the project, use material and tools, arrange solutions, and calculate the results mathematically, influencing students scientifically literacy skills. In STEM Education, the student will be capable to literate scientifically and carried out the problem-solving procedures when the student has high problem-solving skills and affects the student's scientific literacy (Yuliati et al., 2018). Meanwhile, Idawati et al., (2019) explained that Learning through an inquiry-based authentic learning approach in the STEM program holds higher literacy skills to students who have low problem-solving abilities than the student using the conventional learning concept.

\section{CONCLUSION}

The research results discussion concludes the validity and feasibility of the STEM-based module on optical instrument material used in distance learning (elearning) are declared by the experts. Moreover, the implementation of STEM-based modules on optical instrument material through e-learning on students' scientific literacy skills has a moderate effect.

\section{RECOMMENDATION}

In further research, the development of STEM-based science teaching materials is needed in other materials. The STEM approach is considered very suitable for both online and offline learning. Moreover, one of the main obstacles to implementing STEM in distance learning is that some students do not work on projects due to a lack of motivation. Therefore, to overcome the weaknesses in distance learning (elearning), teachers' motivation is also necessary to ensure that students participate actively in learning.

\section{ACKNOWLEDGMENT}

The publication of this research is supported by the Directorate of Research and Community Service, Universitas Muhammadiyah Sidoarjo, through the Applied Research Institution Grant Program with No 177/I1.3.AU/02.00/C/KEP/1/2020. Researchers also want to appreciate the assistance of students in SMA 02 Muhammadiyah Sidoarjo.

\section{REFERENCES}

Afriana, J., Permanasari, A., \& Fitriani, A. (2016). Project based learning integrated to stem to enhance elementary school' $\mathrm{s}$ students scientific literacy Jurnal Pendidikan IPA Indonesia. Jurnal Pendidikan IPA Indonesia, 5(2), 261-267. https:/ / doi.org/10.15294/jpii.v5i2.5493

Anindya, F. A. U., \& Wusqo, I. U. (2020). The Influence of PjBL-STEAM model toward students ' problem-solving skills on light and optical instruments topic. Journal of Physics: Conference Series, 1567(4), 042054. https://doi.org/10.1088/17426596/1567/4/042054 
Buchori, A., \& Setyawati, R. D. (2015). Development learning model of charactereducation through e-comic in elementary school. International Journal of Education and Research, 3(9), 369-386.

Dewati, M., Bhakti, Y. B., Agustina, I., \& Astuti, D. (2019). Peranan Microscope Smartphone sebagai media pembelajaran Fisika berbasis STEM untuk meningkatkan pemahaman konsep Optik. Prosiding SNFA (Seminar Nasional Fisika Dan Aplikasinya) 2019, 36-42.

Dewi, C. A., Khery, Y., \& Erna, M. (2019). An Ethnoscience Study In Chemistry Learning To Develop Scientific Literacy. Jurnal Pendidikan IPA Indonesia, 8(2), 279287. https:// doi.org/10.15294/jpii.v8i2.19261

Galili, I., \& Hazan, A. (2000). Learners' knowledge in optics: interpretation, structure and analysis. International Journal of Science Education, 22(1), 57-88. https:/ / doi.org/https:/ / doi.org/10.1080/095006900290000

HACIOĞLU, Y., YAMAK, H., \& KAVAK, N. (2016). Pre- Service Science Teachers ' Cognitive Structures Regarding Science, Technology, Engineering, Mathematics (STEM) and Science Education. Journal of Turkish Science Education, 13(Special Issue), 88-102. https:/ / doi.org/10.12973/tused.10173a

Hake, R. R. (1999). Analyzing change/gain scores. American Educational Research Association, 1-4.

Idawati, Muhardjito, \& Yuliati, L. (2019). Authentic Learning Berbasis Inquiry dalam Program STEM terhadap Literasi Saintifik Siswa Berdasarkan Tingkatan Kemampuan Pemecahan Masalah Siswa. Jurnal Pendidikan: Teori, Penelitian, Dan Pengembangan, 4(8), 1024-1029. http://journal.um.ac.id/index.php/jptpp/

Ismail, I., Permanasari, A., \& Setiawan, W. (2016). Efektivitas Virtual Lab Berbasis STEM dalam Meningkatkan Literasi Sains Siswa dengan Perbedaan Gender STEM-Based Virtual Lab Effectiveness in Improving the Scientific Literacy of Students with Gender Differences. Jurnal Inovasi Pendidikan IPA, 2(2), 190-201.

Kelley, T. R., \& Knowles, J. G. (2016). A conceptual framework for integrated STEM education. International Journal of STEM Education, 3(11), 1-11. https:/ / doi.org/10.1186/ s40594-016-0046-z

Khaeroningtyas, N., Permanasari, A., \& Hamidah, I. (2016). Stem learning in material of temperature and its change to improve scientific literacy of junior high school students. Jurnal Pendidikan IPA Indonesia, 5(1), 94-100. https://doi.org/10.15294/jpii.v5i1.5797

Lestari, H., Rahmawati, I., Siskandar, R., \& Dafenta, H. (2021). Implementation of Blended Learning with A STEM Approach to Improve Student Scientific Literacy Skills During The Covid-19 Pandemic. Jurnal Penelitian Pendidikan IPA, 7(2), 224231. https:// doi.org/https:/ / doi.org/10.29303/jppipa.v7i2.654

Ling, T. W. (2017). Fostering Understanding and Reducing Misconceptions About Image Formation by a Plane Mirror Using Constructivist-Based Hands-on Activities. In In Overcoming Students' Misconceptions in Science (pp. 203-222). Springer Singapore. https:/ / doi.org/DOI: 10.1007/978-981-10-3437-4_11

Listiana, Abdurrahman, Suyatna, A., \& Nuangchalerm, P. (2019). The Effect Of Newtonian Dynamics Stem-Integrated Learning Strategy To Increase Scientific Literacy. Jurnal Ilmiah Pendidikan Fisika Al-Biruni, 08(1), 43-52. https:/ / doi.org/10.24042/jipfalbiruni.v8i1.2536

Muliani, Marhami, \& Lukman, I. R. (2021). Persepsi Mahasiswa Calon Guru Tentang Literasi Sains. Jurnal Ilmu Sosial Dan Pendidikan, 5(1), 238-244. 
Muswita, Yelianti, U., Intan, A., \& Kusuma, L. (2020). The Development of Booklet on the Subject Matter of Ferns (Pteridophytes) from the Sultan Thaha Syaifuddin's Forest Park as Enrichment Material of Plant Taxonomy Course. Biodik: Jurnal Ilmiah Pendidikan Biologi, 6(1), 58-75. https:// doi.org/10.22437/bio.v6i1.8642

Nurtanto, M., Nurhaji, S., Widjanarko, D., Wijaya, M. B. R., \& Sofyan, H. (2018). Comparison of Scientific Literacy in Engine Tune-up Competencies through Guided Problem-Based Learning and Non-Integrated Problem-Based Learning in Vocational Education. Journal of Physics: Conference Series, 1114(1). https:/ / doi.org/10.1088/1742-6596/1114/1/012038

OECD. (2019). Programme for International Students Assessment (PISA) Results From PISA 2018.

Oliveira, M. M. S. de, Penedo, A. sergio T., \& Pereira, V. S. (2018). Distance education : advantages and disadvantages of the point of view of education and society. Dialogia, 29, 139-152. https://doi.org/10.5585/Dialogia.n29.7661

Panjaitan, R. G. P., Titin, \& Wahyuni, E. S. (2021). Kelayakan Booklet Inventarisasi Tumbuhan Berkhasiat Obat Sebagai Media Pembelajaran Ruqiah Ganda Putri Panjaitan *, Titin , Eko Sri Wahyuni Pendahuluan Metode. Jurnal Pendidikan Sains Indonesia (Indonesian Journal of Science Education), 9(1), 11-21. https:/ / doi.org/10.24815/jpsi.v9i1.17966

Paramita, R., Ganda, R., Panjaitan, P., Ariyati, E., Paramita, R., Ipa, P., \& No, V . (2018). Pengembangan Booklet Hasil Inventarisasi Tumbuhan Obat Sebagai Media Pembelajaran Pada Materi Manfaat Keanekaragaman Hayati. Jurnal IPA $\mathcal{E}$ Pembelajaran IPA, 02(02).

Picciano, A. G. (2017). Theories and Frameworks for Online Education : Seeking an Integrated Model. Online Learning, 21(3), 166-190. https://doi.org/10.24059/olj.v21i3.1225

Prasetyo, D., Marianti, A., \& Alimah, S. (2021). Improvement of Students ' Science Literacy Skills Using STEM-Based. Journal of Innovative Science Education, 10(37), 216-221.

Puspitasari, I. D., Suhardi, E., Ardianto, D., \& Arif, A. (2019). Pengembangan Bahan Ajar Bermuatan Konteks Kelautan Untuk Meningkatkan Literasi Sains Siswa. JIPI (Jurnal IPA Dan Pembelajaran IPA), 3(2), 88-105. https://doi.org/10.24815/jipi.v3i2.14847

Rahayu, S. (2017). Promoting the 21st century scientific literacy skills through innovative chemistry instruction. AIP Conference Proceedings, 1911(December). https:/ / doi.org/10.1063/1.5016018

Risdianto, E., Fitria, J., Johan, H., \& Macariola, J. S. (2020). Teacher' s Perception of Thermodynamic Law Module Developed in Training through Student ' s Critical Thinking Skills. Journal of Social Work and Science Education, 1(1), 78-86.

Rizawayani, R., Sari, S. A., \& Safitri, R. (2017). Pengembangan Media Poster Pada Materi Struktur Atom Di Sma Negeri 12 Banda Aceh. Jurnal Pendidikan Sains Indonesia (Indonesian Journal of Science Education), 05(01), 127-133.

Rusilowati, A., Kurniawati, L., Nugroho, S. E., \& Widiyatmoko, A. (2016). Developing an instrument of scientific literacy asessment on the cycle theme. International Journal of Environmental and Science Education, 11(12), 5718-5727.

Sinaga, P., Kaniawati, I., \& Andhy, S. (2017). Improving Secondary School Students ' Scientific Literacy Ability Through The Design Of Better Science Textbooks. Journal of Turkish Science Education, 14(4), 92-107. 
https://doi.org/10.12973/tused.10215a

van Laar, E., van Deursen, A. J. A. M., van Dijk, J. A. G. M., \& de Haan, J. (2017). The relation between 21st-century skills and digital skills: A systematic literature review. Computers in Human Behavior, 72, 577-588. https:/ / doi.org/10.1016/j.chb.2017.03.010

Wahyu, Y., Suastra, I. W., Sadia, I. W., \& Suarni, N. K. (2020). The Effectiveness of Mobile Augmented Reality Assisted STEM-Based Learning on Scientific Literacy and Students ' Achievement. International Journal of Instruction, 13(3), 343-356.

Widarti, H. R., Rokhim, D. A., \& Syafruddin, A. B. (2020). The Development Of Electrolysis Cell Teaching Material Based On Stem-Pjbl Approach Assisted By Learning Video : A Need Analysis. Jurnal Pendidikan Fisika Indonesia, 9(3), 309-318. https://doi.org/10.15294/jpii.v9i3.25199

Widayoko, A., Latifah, E., Yuliati, L., \& Fisika, P. (2018). Peningkatan Kompetensi Literasi Saintifik Siswa SMA dengan Bahan Ajar Terintegrasi STEM pada Materi Impuls dan Momentum. Jurnal Pendidikan: Teori, Penelitian, Dan Pengembangan, 3(11), 1463-1467. http:/ /journal.um.ac.id/index.php/jptpp/

Widya, W., Rifandi, R., \& Rahmi, Y. L. (2019). STEM education to fulfil the 21 century demand: a literature review. IOP Conf. Series: Journal of Physics, 012208. https:/ / doi.org/10.1088/1742-6596/1317/1/012208

Yuliati, L., Parno, Hapsari, A. A., Nurhidayah, F., \& Halim, L. (2018). Building Scientific Literacy and Physics Problem Solving Skills through Inquiry-Based Learning for STEM Education. Journal of Physics: Conference Series PAPER, 1108 012026. https:/ / doi.org/10.1088/1742-6596/1108/1/012026 